\title{
What Is a Civil War?A Critical Review of Its Definition and (Econometric) Consequences
}

\section{Mark Gersovitz • Norma Kriger}

We argue that the academic literature, both qualitative and quantitative, has mislabeled most episodes of large-scale violence in Africa as civil wars; these episodes better fit our concept of regional war complexes. Our paper seeks to highlight the fundamental flaws in the conception of civil war in the econometric literature and their implications for econometric specification and estimation, problems that this literature is inherently incapable of rectifying. We advocate the comparative study of regional war complexes in Africa based on historical narratives. JEL codes: D74, H56, O10

\section{Preliminaries}

Civil wars and similar large-scale violence bring death, injury, disease, displacement, and misery. The impairment of the state diminishes its provision of protection for people and property and of basic social services, such as health care and education. Private economic activity becomes difficult or impossible. People want to understand these episodes and how they can be avoided.

This essay focuses on two broad fatal flaws in the econometric literature on civil war, a large and rapidly growing body of literature that has received considerable attention (for surveys, see Collier and Hoeffler 2007; Dixon 2009; Blattman and Miguel 2010). First, rather than providing a definition of civil war, econometric studies use a coding rule based on battle deaths (or, sometimes, any deaths) associated with civil war. Second, these studies apply econometric techniques that cannot address the spatial and temporal aspects of large-scale violence. (We leave aside questions of bidirectional causality between the dependent and so-called independent variables that plague all econometric studies using country-level data.) 
A good definition of civil war is an essential starting point for analysis. The definition of civil war informs the universe of potential cases that can be compared with respect to their causes, dynamics, consequences, termination, and any other concerns, such as postwar reconstruction and rehabilitation. Moreover, the definition of civil war is critical for identifying trends in the nature and location of different types of warfare. After defining civil war, we critique the coding rules based on the number of deaths used by econometric studies and the properties of the data produced by such coding rules. We pay particular attention to the temporal and spatial properties of these data and their implications for econometric specification and estimation. We also develop our critique of the econometric literature on civil war through the use of narratives of historical experiences of large-scale violence. This qualitative approach leads us to understand these episodes of large-scale violence as regional war complexes. We consider both the historical comparative method and the concept of a regional war complex to be promising ways forward in the study of large-scale violence. We limit our examples of civil wars and how to analyze them to Africa only because this region is our area of primary specialization and we have first-hand experience with this region. Africa is a region that suffers from largescale violence.

\section{A Definition of Civil War}

No abstract definition of civil war can provide a set of necessary and sufficient conditions that can be applied mechanically. Even with a good abstract definition of civil war, the process of classifying which countries have experienced civil wars and when inevitably involves judgments based on close reading of the historical narratives of country experiences with large-scale violence. Not all countries will share all dimensions in the definition of civil war.

We are reassured by our position's affinity to the classic discussion of the problems of definition illustrated by Wittgenstein $(1958, \S 66)$ in his examination of the definition of "games.” He concluded: “ . . . we see a complicated network of similarities overlapping and criss-crossing: sometimes overall similarities, sometimes similarities of detail." Therefore, the best that can be done in providing a definition of "games" is a list of activities that one believes should be classified as games and some general commentary on the similarities that some or others of them share. We believe that the concept of civil war shares some attributes of such a familyresemblance concept.

We define a civil war as a politically organized, large-scale, sustained, physically violent conflict that occurs within a country principally among large/numerically important groups of its inhabitants or citizens over the monopoly of physical force 
within the country. Civil wars usually have incumbent governments that control the state and have a monopoly of force before the civil war and challengers-people who have not effectively challenged the monopoly of others before the outbreak of the civil war but whose challenge initiates the outbreak of the civil war. The challengers may begin as a small group, but for the episode to rise to the level of a civil war, they must become numerically important. The challengers may seek to replace the incumbents in control of the monopoly of force within the extant territory of the state, or they may seek the secession of part of the original territory. The achievement of their goals must be plausible. A civil war is not just a sufficiently large group of people over a sufficiently long time who make trouble for the government and undermine security, such as large drug cartels, because they do not aim to possess the monopoly of force. Civil wars must entail large-scale and sustained internal political violence to distinguish them from intense but limited episodes of political violence that contest the monopoly of force, such as political assassinations, mutinies, or coups. Civil war violence may involve external actors, but the violence occurs within the boundaries of a country and predominantly involves internal actors. This last characteristic of our definition is perhaps the most problematic because almost all violence that is called a civil war has some external dimension. We return to this issue in the section on regional wars. Although our conception is narrow, we believe that the elements of other violent internal political conflict are critical to understanding the causes of civil war. In short, we prefer a narrow definition and a broad analysis.

Our definition, like many others, derives, in part, from Max Weber's classic characterization of the state: ". . . the state is that human community which within a defined territory successfully claims for itself the monopoly of legitimate physical force; and 'territory'. . . is a characteristic of the state.... The state is the sole source for the 'right' to exercise violence" (Weber, 2004, 131-32). Thus, for us, at a minimum, civil war is one form of the impairment of the state. Unlike Weber, we do not mention legitimacy; if a tyrant can maintain the uncontested monopoly of force, there is no civil war. We also draw selectively on various authors on civil wars, most of whom provide requisites of civil war rather than abstract definitions (Fearon 2007; Kalyvas 2006; Edmonds 1972; Keegan and Bull 2006). These authors differ on numerous issues, including how broadly they conceive of wars (e.g., the inclusion of guerrilla insurgencies or only conventional military warfare), the importance of mass participation in violent conflict, and the importance of whether the war is fought exclusively by nationals or whether only most combatants must be nationals. On one issue, there is broad consensus: civil war violence takes place within the country.

Not all authors subscribe to the merits of defining civil war. Some authors (e.g., Cramer 2007, especially ch.2; Bøås and Dunn 2007, 4) believe it may be dangerous to isolate civil war as a discrete phenomenon. For example, Cramer $(2007,51)$ fears 
that focusing on civil wars "produces a misleading idea that violent conflict is a relatively rare phenomenon." Cramer and those who share his conceptual critique of civil war prefer to conceive of violence as a continuum. We take from these critics the important caution that the absence of civil war is not necessarily peace, as it is in the quantitative literature based on death counts, and that one should expect to find prior to a civil war the violent origins of the war itself. However, the notion of a continuum of violence shares a fundamental weakness with the 1960s concept of internal war, which included almost all forms of violence against authority: assassinations, coups, rebellions, revolutions, and civil wars (Eckstein 1964 and 1965; Rosenau 1964; Luard 1972). There are too many disparate phenomena under simultaneous consideration. We therefore remain committed to the a priori value of a definition of civil war. Baev $(2007,248)$, writing on post-Soviet conflicts, challenges the rationale "for drawing firm analytical borders by exploring several "gray areas' where civil war becomes barely distinguishable from other forms of violence." This position is shared by Salehyan (2009), who considers the distinction between civil wars and international wars to be arbitrary (p. 15), although he persists in using both terms in his study of transnational rebels. We are committed to a rigorous definition of civil war, but we share Baev's $(2007,247)$ belief that "only very nuanced examination rather than application of rigid criteria could help in distinguishing civil wars from other crises."

We now discuss how to implement an abstract definition of the type that we have provided as well as the pitfalls inherent in the application of the coding rules used in the econometric literature. We focus on two dimensions of our definition of civil war: "large-scale, sustained, physically violent conflict" (the temporal dimension) and conflict "among large/numerically important groups of its inhabitants or citizens" (the spatial dimension).

\section{Large-Scale, Sustained, Physically Violent Conflict}

Now, we focus on the part of our definition that refers to large-scale, sustained violent conflict. One measure of physical violence is the number of people killed as a result of a violent conflict over the monopoly of force. This general intuition is the basis for the coding rule in the quantitative literature. In this section, our goal is to explain and assess the rules that econometric studies use to code civil wars and three time-series properties of the data that they produce: the number of countries reported as having civil wars, the extent to which these wars are coded as being sustained (as we believe from the narratives that they are), and the correlation over time of whether a country is reported as having a civil war. In econometric terms, the first two properties of the data correspond to errors in variables, and the last property corresponds to autocorrelation in the dependent variable. 
The most recent set of data used widely by econometric researchers is the Armed Conflict Dataset of the International Peace Research Institute of Oslo and the Department of Peace and Conflict Research, Uppsala University (hereinafter PRIO/ Uppsala), discussed in Gleditsch et al. (2002) and documented in the codebook of Strand et al. (2005). This data set is available in various versions. We do not use the most recent one to remain as consistent as possible with the published studies on which we comment. The codebook defines four types of conflict in which a country can be involved (Strand et al. 2005, 10). Two types of conflict are relevant to our discussion because they are used in econometric studies of civil war: "[type] 3. Internal armed conflict occurs between the government of a state and internal opposition groups without intervention from other states. [type] 4. Internationalized internal armed conflict occurs between the government of a state and internal opposition groups with intervention from other states." A type 4 conflict is qualified by the variable "location," which identifies whether the country that is coded as involved in a type 4 conflict experienced violence in its territory. The data set codes each type of conflict into three categories of intensity, of which the first two are "not ordinal": "1. Minor: At least 25 battle-related deaths per year for every year in the period. 2. Intermediate: More than 25 battle-related deaths per year and a total conflict history of more than 1000 battle-related deaths, but fewer than 1000 per year. 3. War: At least 1000 battle-related deaths per year" (Strand et al. 2005, 10).

Table 1 presents, in compact form, the entire PRIO/Uppsala data (Version 3) for the countries on the African continent for the years 1960-2004. In the original data set, the categories type 3 and type 4 are not mutually exclusive. Table 1, however, presents the data in categories that are mutually exclusive and exhaustive so that all the information in any cell (country-year) can be represented by only one symbol. For countries with two rows of codes, in the top row (row 1) our coding is as follows: An X denotes conflicts that are type 3 ("internal") at intensity 3 ("war") if PRIO/Uppsala does not also designate a type 4 conflict at intensity 3 in that year. An I denotes a type 4 ("internationalized internal") conflict at intensity 3 in which the "location" of the conflict was within the country if PRIO/Uppsala does not also designate a type 3 conflict at intensity 3 in that year. An O denotes years that PRIO/ Uppsala designates as both type 3 and type 4 (and the location of the type 4 conflict is within the country), each at intensity 3 (i.e., there is overlap according to the $\mathrm{PRIO} /$ Uppsala data). An F denotes type 4 conflicts of intensity 3 in which a country was involved but for which the location was outside that country. There are no countries that have years in which PRIO/Uppsala designates a type 3 conflict and a type 4 conflict with a location outside the country. A blank denotes a year of no conflict of either type 3 or type 4 at intensity 3 , in effect a year of peace in the coding used by the econometric studies if they use intensity 3 data. In the bottom row (or the only row for countries with only one row; row 2), X, I, O, F, and blank 
Table 1. Years of "Internal Armed Conflict" or "Internationalized Internal Armed Conflict" in Africa, 1960-2004 (Gleditsch et al. [2002] and Strand [2005] Data)

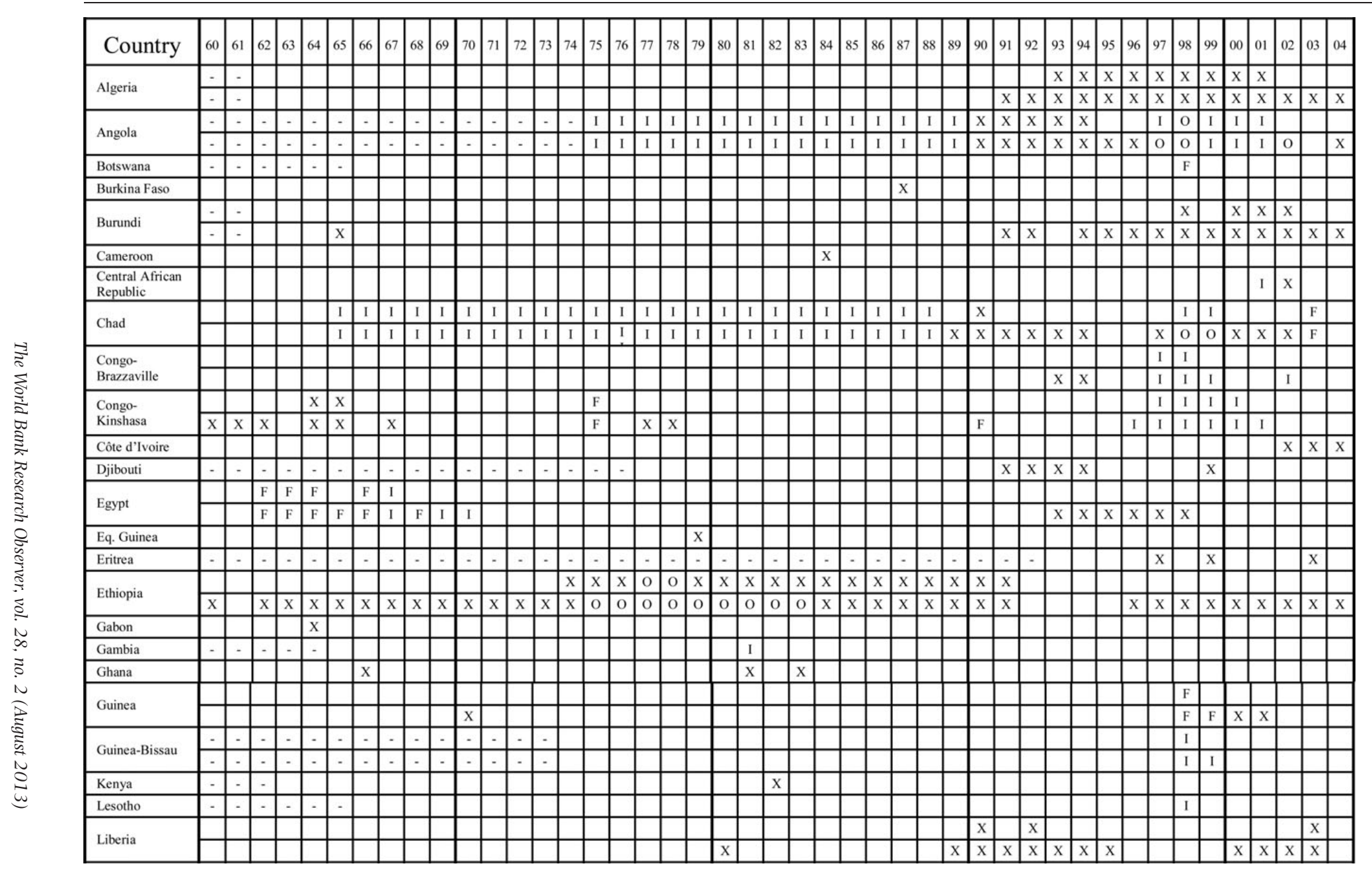




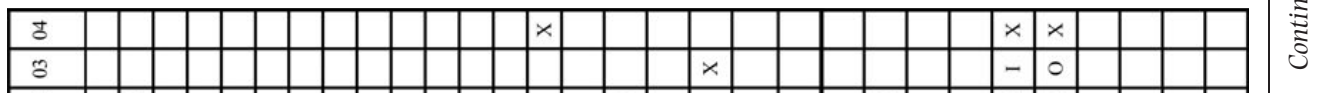

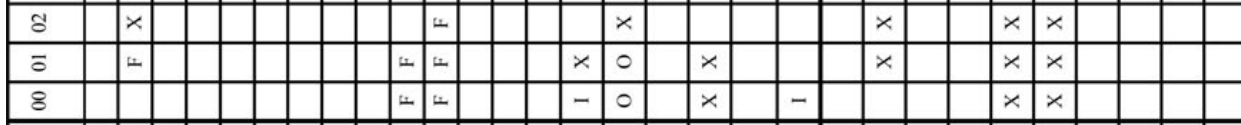

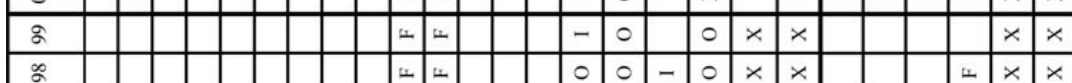

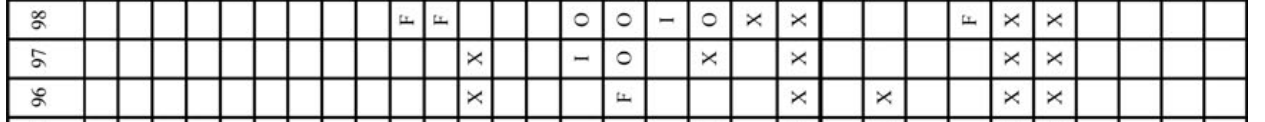

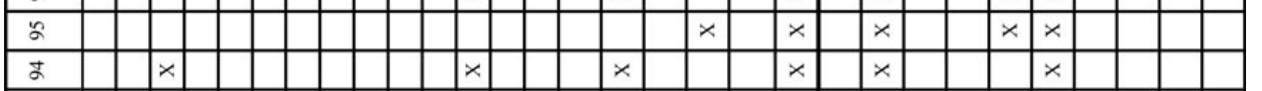

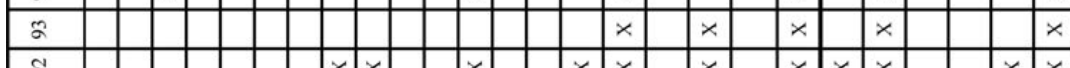

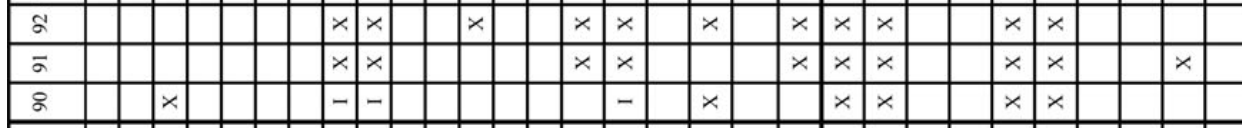

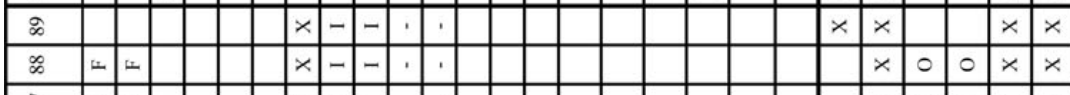

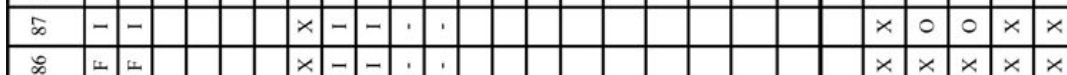

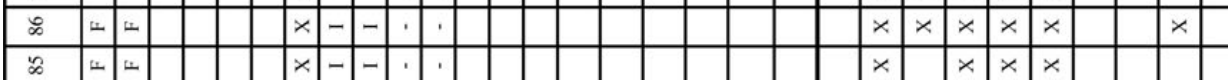

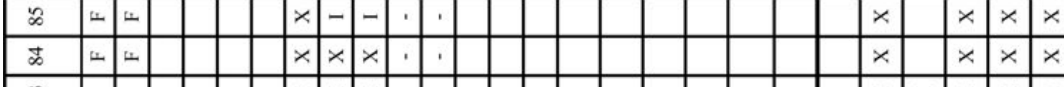

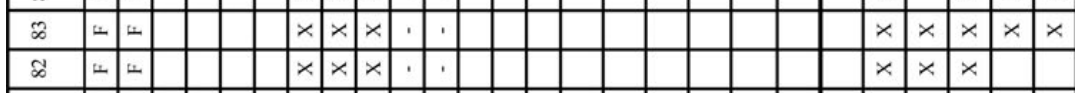

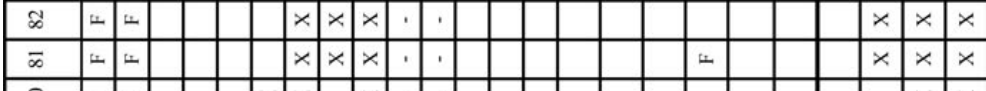

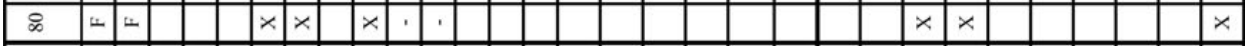

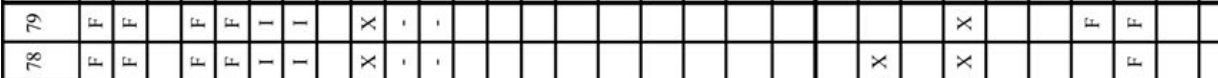

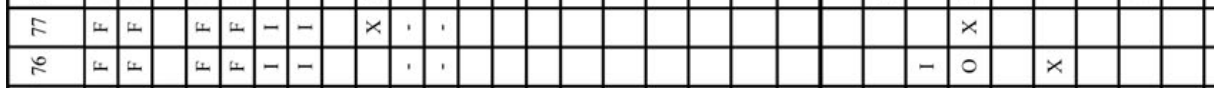

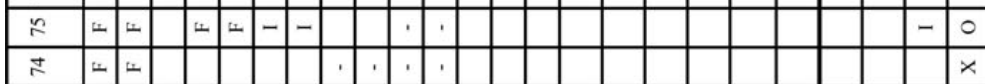

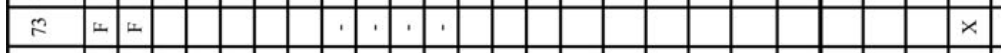

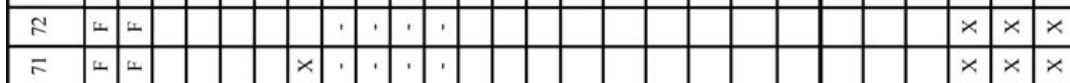

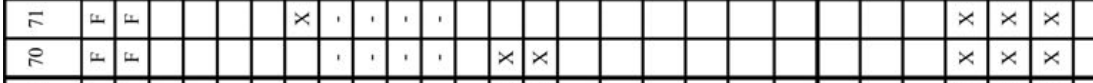

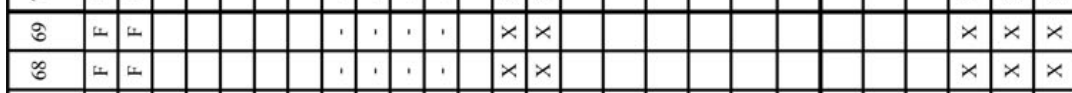

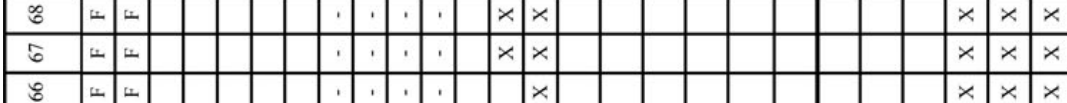

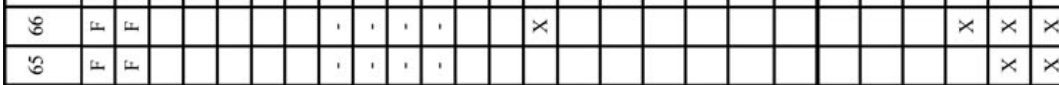

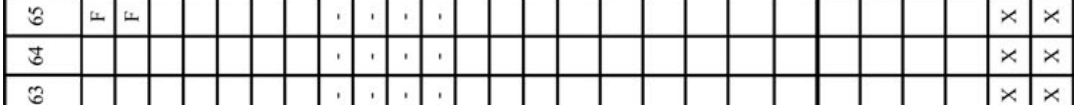

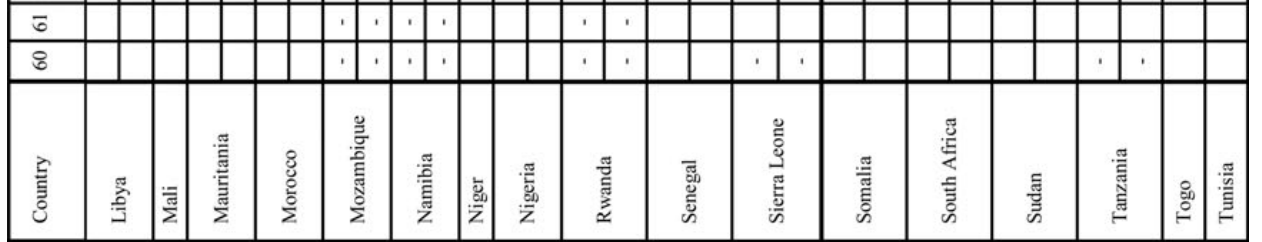


Table 1. Continued

\begin{tabular}{|c|c|c|c|c|c|c|c|c|c|c|c|c|c|c|c|c|c|c|c|c|c|c|c|c|c|c|c|c|c|c|c|c|c|c|c|c|c|c|c|c|c|}
\hline Country & 60 & 61 & 62 & 63 & 64 & 65 & 66 & $\begin{array}{lll}67 & 6\end{array}$ & $\begin{array}{ll}8 & 69\end{array}$ & 70 & 71 & 72 & 73 & 74. & 757 & 677 & 778 & 79 & 80 & 81 & 82 & \begin{tabular}{l|l}
83 & 8
\end{tabular} & 34 & 58 & $\begin{array}{ll}6 & 87\end{array}$ & 88 & 89 & 90 & 91 & 92 & 93 & 94 & & 96 & & 98 & & & & 203 & 04 \\
\hline \multirow{2}{*}{ Uganda } & - & - & & & & & & & & & & & & & & & & I & & \begin{tabular}{|l|l|}
$x$ & \\
\end{tabular} & \begin{tabular}{l|l}
$x$ \\
\end{tabular} & \begin{tabular}{l|l}
$x$ & $x$ \\
\end{tabular} & $x$ & $\begin{array}{l}x \\
x\end{array}$ & \begin{tabular}{l|l}
$x$ & $x$ \\
\end{tabular} & $x$ & $x$ & & $x$ & & & & & & I & I & I & 1 & & & $x$ \\
\hline & - & - & & & & & & & & & $x$ & $\mathrm{x}$ & & & & $\mathrm{x}$ & \begin{tabular}{|l|l|} 
\\
\end{tabular} & I & & \begin{tabular}{|l|l|}
$x$ & \\
\end{tabular} & \begin{tabular}{l|l}
$x$ \\
\end{tabular} & \begin{tabular}{l|l}
$x$ & $x$ \\
\end{tabular} & $x$ & $\begin{array}{l}x \\
x\end{array}$ & \begin{tabular}{l|l}
$x$ & $x$ \\
\end{tabular} & $x$ & $x$ & $x$ & $x$ & & & \begin{tabular}{l|l}
$x$ \\
\end{tabular} & \begin{tabular}{l|l} 
\\
\end{tabular} & 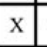 & \begin{tabular}{l|l} 
\\
\end{tabular} & \begin{tabular}{l|l} 
\\
\end{tabular} & \begin{tabular}{l|l} 
\\
\end{tabular} & \begin{tabular}{l|l} 
o \\
\end{tabular} & \begin{tabular}{l|l}
0 & $x$ \\
\end{tabular} & $x$ & $\mathrm{x}$ \\
\hline \multirow{2}{*}{ Zimbabwe } &. & - & - & $\theta^{-}$ & - & & & & & & & & & & 2 & \begin{tabular}{l|l}
$x$ & $x$ \\
\end{tabular} & $x$ & $\mathrm{x}$ & & & & & 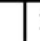 & \begin{tabular}{l|l}
$F$ & 1
\end{tabular} & \begin{tabular}{l|l}
$F$ & $F$ \\
\end{tabular} & F & $\mathrm{F}$ & F & & & & & & & & \begin{tabular}{l|l}
$\mathrm{F}$ \\
\end{tabular} & $\mathrm{F}$ & $\mathrm{F}$ & & & \\
\hline & - & - & - & - & - & & & & & & & $\mathrm{x}$ & $\mathrm{x}$ & $\mathrm{x}$ & \begin{tabular}{l|l}
$\mathrm{x}$ & 2 \\
\end{tabular} & \begin{tabular}{l|l}
$x$ & $x$ \\
\end{tabular} & $x$ & $\mathrm{x}$ & & & & & 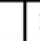 & 1 & \begin{tabular}{l|l}
$F$ & $F$ \\
\end{tabular} & F & $\mathrm{F}$ & F & & & & & & & & $\mathrm{F}$ & $\mathrm{F}$ & $\mathrm{F}$ & $\mathrm{F}$ & & \\
\hline
\end{tabular}

Notes: The top row for each country is the "1,000 deaths" definition (intensity 3), and the bottom row is the all-intensities definition (intensities 1-3) (see text).

A year in which only an "internal armed conflict" occurred is denoted by X, a year in which only an "internationalized internal armed conflict" occurred in the country under consideration ("location" > 0) is denoted by I, and a year in which both occurred is denoted by O. A year of "internationalized internal armed conflict" in which the country participated as an intervener but violence did not occur within its territories ("location" $=0$ ) is denoted by F.

Taken together, years with an X, I, or O are instances of civil war in the MGB studies, and an empty cell is a year of peace (see text).

An entry of a "-" is a year before PRIO/Uppsala began to report, usually a year preceding independence.

If the table shows only one row for a country, it is equivalent to the bottom row for countries with two rows and means that no years were designated as intensity 3 in the PRIO/Uppsala data.

African countries for which the data set reports no year of "internal armed conflict" or "internationalized internal armed conflict" of intensity 1, 2, or 3 between 1960 and 2004 are Benin, Malawi, Swaziland, and Zambia.

Source: All data come from the PRIO/Uppsala Version 3 STATA data set Monadic_Table.dta, downloaded January 17, 2006. 
have the same meanings as just discussed except that the intensity is 1-3 ("minor," "intermediate," or "war") rather than intensity 3 alone.

Among the econometric studies that have recoded the PRIO/Uppsala data to study aspects of civil war, we provide three examples: Miguel et al. (2004), Gleditsch (2007), and Buhaug and Gleditsch (2008) (hereinafter MGB). Miguel et al. (2004) study whether countries in sub-Saharan Africa had a civil war for each of the years 1981 to 1999. Because they used a slightly earlier version of the data, their table $\mathrm{C} 1$ is not identical to our table 1 when the two tables overlap, but they seem close and consistent in their method of construction. Miguel et al. (2004, 730-31, and table $\mathrm{C} 1$ ) seem to use primarily the union of the X, I, O, and F data at intensities 1-3 (corresponding to the concepts in row 2 of table 1), but they also present some results based on intensity 3 (row 1 of table 1). In a study of the onset of civil war, Gleditsch $(2007,300-01)$ seems to do the same but considers only states in which conflict has erupted to have had an onset of civil war, seemingly excluding our $\mathrm{F}$ coding. Buhaug and Gleditsch's $(2008,223)$ study of civil war onset also seems to use the union of $X, I$, and $O$ data for intensities 1-3. Earlier quantitative studies using different data also code a civil war by a battle-death count, usually of at least 1,000 per year (Licklider 1995), or more than 1,000 battle-related deaths in any major conflict (Wallensteen and Sollenberg 1999, 595). Thus, the most recent studies seem to favor the lower threshold of row 2, but the earlier studies favored a higher threshold, similar to that of row 1 . As argued below, both approaches have serious shortcomings.

Deaths related to a conflict are difficult to estimate, a point well made by Cramer (2007, table 1). Furthermore, "battle" is a strange modifier of deaths when most of the violence that is considered part of civil wars in these data sets does not involve set-piece battles, making it difficult to know what a battlefield death is. This modifier is especially problematic because these episodes often involve civilian deaths. These deaths hardly ever seem to occur on a battlefield, and certainly not in a case like Sierra Leone, where terrorizing civilians in their villages and homes was a prevalent strategy during the conflict. Similar situations occur when civilians in camps for refugees or internally displaced persons are targets, as in Darfur, Congo-Kinshasa, Burundi, or Rwanda. Some researchers employ a count of any death associated with large-scale violence (whether civilian or battle deaths) to identify a civil war. Doyle and Sambanis's $(2000 \mathrm{~b}, 3)$ coding of wars "uses the 1,000 deaths threshold for the entire war as long as the war caused 1,000 deaths in any single year [sic]." To code the onset of a civil war, Fearon and Laitin (2003a, 76) require at least 1,000 deaths over its course, with a yearly average of at least 100 deaths.

Ultimately, the battle deaths are coded as 0 or 1 depending on whether the threshold of 1,000 deaths was met. It is not possible to use most of these data sets to obtain the actual number of deaths. Large countries tend to be more likely to meet the threshold and to be coded as having had civil wars. This may be why at least 
some of these data sets ignore many violent episodes in the smaller countries of Africa that are widely thought to be civil wars, as discussed below. There are other problems with a definition of civil war based on the numbers and years of deaths (Sambanis 2004; Cramer 2007). Perhaps most telling is Sambanis's (2004, 835) conclusion from his correlation analysis of the coding of civil wars in the data sets that "there is still considerable disagreement about which armed conflicts should be classified as civil wars. Many wars are coded in only one out of a dozen data sets." This disagreement among data sets is illustrated in both tables 1 and 2 . Furthermore, Sambanis shows that the choices in assembling these data on civil war-related deaths affect econometric and other inferences.

The whole focus on deaths relies on a concept of active violence rather than one of potential violence. A contest for the monopoly of force in a country can be under way without involving large numbers of deaths, such as if some areas of a country become no-go zones for the government, as evidenced by anecdotal accounts or the inability to raise revenues from an area. Côte d'Ivoire did not meet a 1,000-death threshold, so there is no row 1 reported for it in table 1 . Nonetheless, there were many years in the 2000s when few people would have wanted to drive from Abidjan to Bouaké. Foreign forces were barely keeping the two sides apart, and the country was experiencing a de facto partition, the very essence of a contestation of the monopoly of force and civil war. For this and other reasons, Côte d'Ivoire is an important case, to which we return later.

When does one war end and a new one begin? Our criterion is that the contest over the monopoly of force has ended for the foreseeable future, not that there has been a period that is free of a certain type and number of deaths, as in the econometric literature. Ironically, to determine a war's end, many researchers who pursue an econometric approach rely on their judgment rather than making exclusive use of their own mechanical coding rules. For example, Licklider identifies a civil war as having ended when there is an end to concerns about living together, an end to multiple sovereignty or fewer than 1,000 battle deaths in each of five years (Licklider 1995, 682, 685). Doyle and Sambanis (2000a, 783) determine that a war has ended if "an end to the war and to residual lower-level violence and uncontested sovereignty" has occurred for two years. Doyle and Sambanis $(2000 b, 3)$ provide somewhat more detailed "rules of thumb" for determining a war's end on the basis of, among other criteria, peace settlements, a dramatic change in the parties, or case study literature that determines that there was a single war. We are sympathetic with such a multidimensional approach.

What happens when one attempts to determine whether one war has ended and a new one has begun or whether there has been one continuous conflict in a particular case, say the case of Zimbabwe? Both Licklider (1995) and Doyle and Sambanis (2000a, 2006) identify Zimbabwe as having had two separate wars (table 2), but they date the wars slightly differently. For Licklider, the first war was from 1972 to 1980; for Doyle and Sambanis (2006), it was from 1972 to 1979. 
Table 2. Classification of Civil Wars: Some Alternatives in the Literature

\begin{tabular}{|c|c|c|c|c|c|c|c|c|c|c|c|c|c|c|c|c|c|c|c|c|c|c|c|c|c|c|c|c|c|c|c|c|c|c|c|c|c|c|c|c|c|c|}
\hline Country & & 60 & 61 & 62 & 63 & 64 & 65 & 66 & \begin{tabular}{l|l}
67 & 6
\end{tabular} & 68 & 7 & 071 & 72 & 73 & 74 & 75 & \begin{tabular}{l|l}
76 & 7 \\
7
\end{tabular} & $77 \begin{array}{l}7 \\
79\end{array}$ & \begin{tabular}{l|l}
78 & 7
\end{tabular} & \begin{tabular}{l|l}
79 & 8
\end{tabular} & 81 & 82 & 83 & 84 & \begin{tabular}{l|l}
85 & 8 \\
8
\end{tabular} & 868 & $\begin{array}{ll}7 & 8\end{array}$ & 89 & 90 & 91 & 92 & 93 & \begin{tabular}{l|l}
94 & 95
\end{tabular} & $\begin{array}{ll}596 \\
9\end{array}$ & 97 & 98 & 99 & 00 & 01 & 02 & \begin{tabular}{l|l}
03 & 0
\end{tabular} & 04 \\
\hline \multirow{5}{*}{ Chad } & $\mathrm{A}$ & & & & & & I & I & \begin{tabular}{l|l} 
\\
\end{tabular} & $\mathrm{I}$ & 1 & I & \begin{tabular}{|l|} 
I \\
\end{tabular} & 1 & $\mathrm{I}$ & \begin{tabular}{|l|l}
1 & \\
\end{tabular} & \begin{tabular}{l|l} 
\\
\end{tabular} & I & \begin{tabular}{l|l}
1 & 1 \\
1
\end{tabular} & \begin{tabular}{l|l}
1 & 1
\end{tabular} & I & \begin{tabular}{|l|} 
I \\
\end{tabular} & $\mathrm{I}$ & I & 1 & $\mathrm{I}$ & T & & $\mathrm{x}$ & & & & & & & \begin{tabular}{|l|l|}
$\mathrm{I}$ \\
\end{tabular} & \begin{tabular}{|l|l|}
$\mathrm{I}$ \\
\end{tabular} & & & & $\mathrm{F}$ & \\
\hline & B & & & & & & 1 & I & \begin{tabular}{l|l}
1 \\
\end{tabular} & I & 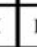 & I & I & I & $\mathrm{I}$ & \begin{tabular}{|l|} 
I \\
\end{tabular} & \begin{tabular}{l|l}
$\mathrm{I}$ & \\
\end{tabular} & \begin{tabular}{l|l}
1 \\
\end{tabular} & \begin{tabular}{l|l}
1 & 1
\end{tabular} & \begin{tabular}{l|l}
1 & 1
\end{tabular} & 1 & I & $\begin{array}{ll}1 \\
\end{array}$ & I & 1 & I & 1 & $x$ & $x$ & $x$ & \begin{tabular}{l|l}
$x$ \\
\end{tabular} & $x$ & \begin{tabular}{l|l}
$x$ &
\end{tabular} & & $\mathrm{x}$ & o & \begin{tabular}{l|l}
0 \\
\end{tabular} & $\mathrm{x}$ & $\mathrm{x}$ & $\mathrm{x}$ & $\mathrm{F}$ & \\
\hline & c & & & & & & 1 & 1 & 1 & 1 & 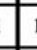 & 1 & 1 & 1 & 1 & 1 & 1 & 11 & 11 & \begin{tabular}{l|l}
1 & 1 \\
\end{tabular} & 1 & 1 & 1 & 1 & 1 & 1 & T & 1 & 1 & 1 & 1 & 1 & \begin{tabular}{l|l}
1,2 & 1, \\
\end{tabular} & $\begin{array}{ll}2 & 1,2 \\
\end{array}$ & 1,2 & 1,2 & \begin{tabular}{|l|}
1 \\
\end{tabular} &. & - & - & - & - \\
\hline & $D$ & & & & & & 1 & 1 & \begin{tabular}{l|l}
1 &
\end{tabular} & 1 & $\pi$ & 1 & 1 & 1 & 1 & \begin{tabular}{|l|}
1 \\
\end{tabular} & 1 & \begin{tabular}{l|l}
1 & 1 \\
\end{tabular} & \begin{tabular}{l|l}
1 & 1 \\
\end{tabular} & \begin{tabular}{l|l}
1 & 2 \\
\end{tabular} & 2 & 2 & 2 & 2 & 2 & 2 & 2 & 2 & 2 & 2 & 2 & 2 & \begin{tabular}{l|l}
2,3 & 3 \\
\end{tabular} & 3 & 3 & 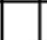 & 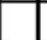 & 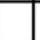 & 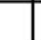 & - &. & - \\
\hline & \begin{tabular}{|l|}
$\mathrm{E}$ \\
\end{tabular} & & & & & & & & & & & & & & & & & & & $x$ & $x$ & $\mathrm{x}$ & $\mathrm{x}$ & $x$ & \begin{tabular}{c|c}
$x$ \\
\end{tabular} & $x=2$ & & & & & & & . & - & -1 & -1 & -1 & -1 & 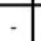 & . &. & -1 \\
\hline \multirow{5}{*}{$\begin{array}{l}\text { Congo- } \\
\text { Brazzaville }\end{array}$} & $\mathrm{A}$ & & & & & & & & & & & & & & & & & & & & & & & & & & & & & & & & 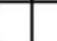 & & 1 & I & & 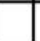 & & - & 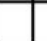 & \\
\hline & B & & & & & & & & & & & & & & & & & & & & & & & & & & & & & & & $\mathrm{x}$ & $x$ & & \begin{tabular}{|l|}
$I$ \\
\end{tabular} & \begin{tabular}{|l|} 
I \\
\end{tabular} & \begin{tabular}{|l|l} 
I \\
\end{tabular} & & & I & 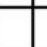 & \\
\hline & C & & & & & & & & & & & & & & & & & & & & & & & & & & & & & & & . & 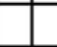 & 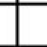 & & $x$ & \begin{tabular}{|l|l|}
$x$ \\
\end{tabular} & - & - & - & - & - \\
\hline & $\mathrm{D}$ & & & & & & & & & & & & & & & & & & & & & & & & & & & & & & & 1 & \begin{tabular}{l|l}
1 & 1
\end{tabular} & 1 & 1 & 2 & \begin{tabular}{|l|l}
2 & \\
\end{tabular} & & 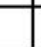 & - & - & - \\
\hline & $\mathrm{E}$ & & & & & & & & & & & & & & & & & & & & & & & & & & & & & & & & - & - & - & -1 & - & - & - & - & - & - \\
\hline \multirow{5}{*}{\begin{tabular}{|l} 
Congo- \\
Kinshasa
\end{tabular}} & \begin{tabular}{|l|}
$\mathrm{A}$ \\
\end{tabular} & & & & & $x$ & $\mathrm{x}$ & & & & & & & & & $\mathrm{F}$ & & & & & & & & & & & & & & & & & & & \begin{tabular}{|l|}
1 \\
\end{tabular} & \begin{tabular}{|l|} 
I \\
\end{tabular} & \begin{tabular}{|l|l}
1 & \\
\end{tabular} & I & & 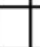 & 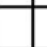 & \\
\hline & B & \begin{tabular}{|l|}
$x$ \\
\end{tabular} & $x$ & $\mathrm{x}$ & & \begin{tabular}{l|l}
$x$ \\
\end{tabular} & $\mathrm{x}$ & & $x$ & & & & & & & $F$ & & \begin{tabular}{l|l}
$x$ & $\lambda$ \\
\end{tabular} & $\mathrm{x}$ & & & & & & & & & & $\mathrm{F}$ & & & & & I & 1 & \begin{tabular}{|l|}
$\mathrm{I}$ \\
\end{tabular} & \begin{tabular}{|l|l|}
$\mathrm{I}$ \\
\end{tabular} & 1 & $\mathrm{I}$ & 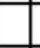 & 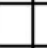 & \\
\hline & c & 1 & 1 & 1 & 1 & 1 & 1 & & & & & & & & & & & 23 & 2 & & & & & & & & & & & & & & & 3 & 3 & 4 & \begin{tabular}{|l|l}
4 & \multicolumn{1}{|c|}{} \\
\end{tabular} & - & - & - & - & - \\
\hline & $\mathrm{D}$ & 1 & 1 & 1 & 1 & 1 & 1 & & 2 & & & & & & & & & 3 & 3 & & & & & & & & & & & & & & & 4 & 4 & 5 & \begin{tabular}{|l|l|}
5 \\
\end{tabular} & 5 & 5 & - & - & 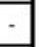 \\
\hline & E & \begin{tabular}{|l|}
1 \\
\end{tabular} & 1 & 1 & 1 & 1 & & & & & & & & & & & & & & & & & & & & & & & & & & & . & - & - & - & - & - & - & - & - & - \\
\hline \multirow{5}{*}{ Zimbabwe } & $\mathrm{A}$ & 4 & - & - & - & - & & & & & & & & & & & \begin{tabular}{l|l}
$x$ & 3 \\
\end{tabular} & \begin{tabular}{l|l}
$x$ & $\gamma$ \\
\end{tabular} & \begin{tabular}{l|l}
$x$ & $x$ \\
\end{tabular} & $\mathrm{x}$ & & & & & & $\mathrm{F}$ & 11 & $\mathrm{~F}$ & $\mathrm{~F}$ & & & & & & & \begin{tabular}{|l|l|} 
\\
\end{tabular} & \begin{tabular}{|l|l|} 
\\
\end{tabular} & $\mathrm{F}$ & & & & \\
\hline & B & - & - & - & - & - & & & & & & & $x$ & $x$ & $\mathrm{x}$ & \begin{tabular}{|l|}
$x$ \\
\end{tabular} & \begin{tabular}{l|l}
$x$ & \\
\end{tabular} & \begin{tabular}{l|l}
$\mathrm{x}$ & $\gamma$
\end{tabular} & \begin{tabular}{l|l}
$x$ & $x$
\end{tabular} & $\mathrm{x}$ & & & 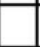 & 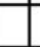 & & \begin{tabular}{l|l}
$\mathrm{F}$ & \\
\end{tabular} & 1 & $F$ & $F$ & & & & & & & F & \begin{tabular}{|l|l|} 
\\
\end{tabular} & \begin{tabular}{|l|}
$F$ \\
\end{tabular} & $\mathrm{~F}$ & 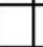 & 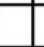 & \\
\hline & c & & & & & & & & & & & & 1 & 1 & 1 & \begin{tabular}{|l|}
1 \\
\end{tabular} & \begin{tabular}{l|l}
1 &
\end{tabular} & 1 & \begin{tabular}{l|l}
1 & 1
\end{tabular} & 1 & & & 2 & 2 & 2 & 2 & & & & & & & & & & & & - & - & - & - & - \\
\hline & D & & & & & & & & & & & & 1 & 1 & 1 & \begin{tabular}{|l|}
1 \\
\end{tabular} & \begin{tabular}{l|l}
1 & \\
\end{tabular} & 1 & \begin{tabular}{l|l}
1 & 1
\end{tabular} & 1 & & & 2 & 2 & 2 & 2 & & & & & & & & & & & & 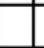 & & - & - & - \\
\hline & $\mathrm{E}$ & & & & & & & & & & & & 1 & 1 & 1 & \begin{tabular}{|l|}
1 \\
\end{tabular} & \begin{tabular}{l|l}
1 & \\
\end{tabular} & 1 & \begin{tabular}{l|l}
1 & 1
\end{tabular} & \begin{tabular}{l|l}
1 & 1 \\
\end{tabular} & & & 2 & 2 & & & & & & & & & & & - & & . & - & - & - & 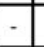 & - \\
\hline
\end{tabular}

Notes: An empty cell denotes no civil war coded by the source, and a "-" denotes that the source ended before this date. For rows labeled A and B, coding is the same as that for rows 1 and 2 in table 1; these data do not distinguish one civil war from another for the same country. For rows labeled C, D, and E, an X denotes a civil war if the source coded only one war; otherwise, a number indicates a year of civil war and which one.

Source: A, table 1, row 1; B, table 1, row 2; C, Fearon and Laitin (2003b); D, Doyle and Sambanis (2006); E, Licklider (1995). 
According to Licklider, the second war was from 1983 to 1984; for Doyle and Sambanis (2000a), the second war occurred in 1984. In subsequent work, Doyle and Sambanis (2006) date the second war from 1983 to 1987. Atlas and Licklider (1999) depict the first war as a "black-white civil war" in which the coalition of two guerrilla forces maintained cohesion against a common white enemy and the second war as "a black-on-black armed conflict between former civil war allies" who "had fought to bring Ian Smith's Rhodesia to an end" (Atlas and Licklider 1999, 40). However, Atlas and Licklider also note that the relationship between the two guerrilla parties and their leaders was fraught even during the first war. Atlas and Licklider's efforts to justify separating the two wars they identify for Zimbabwe actually point to the close connections and inseparability of the two wars. More important, the preoccupation with death counts comes at the expense of understanding the history of how the two violent episodes are connected (Kriger 2003).

A number of general points can be made based on further examination of the PRIO/Uppsala data presented in table 1 . Points $1-4$ relate to nonrandom errors in the classification of the dependent variable, and point 5 addresses the question of autocorrelation.

1. The strictest rule for coding a civil war that seems applicable to the PRIO/ Uppsala data is "internal armed conflict" (type 3, denoted by X and O) and "war" intensity (the threshold based on 1,000 battle deaths in any one year, reported in row 1 for each country that has two rows). Countries with at least one civil war with this criterion are Algeria, Angola, Burundi, Chad, Congo-Kinshasa, Ethiopia, Liberia, Morocco, Mozambique, Nigeria, Rwanda, Sierra Leone, Somalia, South Africa, Sudan, Uganda, and Zimbabwe. These instances of civil war are far fewer than suggested by a cursory reading of the narrative literature on Africa. Cameroon, Central African Republic, Congo-Brazzaville, Côte d'Ivoire, Kenya (Shifta War, 1963 to 1967), Mali, Niger, and Senegal are all plausible cases of civil war, some more than others (however, as we argue in the next section, almost all countries in both groups better fit the definition of participants in a regional war complex).

2. If the coding of civil war is expanded to include "internationalized internal armed conflict" (type 4, denoted by I when there is no overlap with type 3 denoted by $\mathrm{O}$ ) and the intensity continues to be "war," some countries that were not coded as having a civil war now are: Congo-Brazzaville, Egypt, Guinea, Libya, GuineaBissau, and Senegal. In addition, the conflicts of some countries are denoted by F; these countries intervene in violent conflicts in other countries but do not experience associated violence within their own boundaries, which is hardly anyone's idea of a civil war. Mauritania, Namibia, and Tanzania would not even appear in table 1 except for these types of conflicts. Such a conflict seems to be the only reason that Namibia appears in table C1 of Miguel et al. (2004), and such coding is material for their econometric inferences in some cases (Jensen and Gleditsch 
2009). Tanzania seems to appear as a result of its invasion of Uganda after Amin attempted to annex part of Tanzania, so these dates for both countries seem closer to an interstate war than either type of internalized conflict. Ugandan exiles in Tanzania were also involved but probably could not have undertaken hostile action against Amin alone. Libya appears almost only for its interventions, except that in 1987, it was burned in its intervention in Chad, leading to the recording of an I; Libya also reports an X in its row 2 for $2002 .^{1}$

3. Even those countries that would be coded by battle death-based rules as having had civil wars under the "war" intensity (1,000 battle-related deaths) in the PRIO/Uppsala data often show relatively few years of warfare (row 1 of table 1). Similarly, there are often oddly isolated years in what would seem, from narrative accounts, to have been sustained periods of conflict over the monopoly of force. Liberia is such an example, which experienced violent contestations of the monopoly of force following the Doe coup in 1980, beginning with the Dokie raid of 1983, intensifying with the reentry of Taylor in 1989, and continuing at least until the 2003 ouster of Taylor. However, row 1 of table 1 reports only three isolated years of civil war, 1990, 1992, and 2003. (Furthermore, all of these years for Liberia are reported as type 3 conflicts despite the involvement of other African countries in the dynamic of this violence; see the next section on the regional question.)

4. This problem of spotty coverage is mitigated by a more lenient coding rule that is presented in row 2 of table 1 based on fewer deaths (PRIO/Uppsala intensities 1-3) and is the mainstay of the MGB studies. However, a new problem appears. There are country-years that are reported as having instances of so-called civil war under the MGB rules but are unknown to us: Burkina Faso (1987), Burundi (1965), Cameroon (1984), Equatorial Guinea (1979), Ethiopia (1960), Gabon (1964), Gambia (1981), Ghana (1966, 1981, and 1983), Guinea (1970), Kenya (1982), Lesotho (1998), Liberia (1980), Nigeria (2004), Somalia (1978), Togo (1986 and 1991), Tunisia (1980), and Uganda (1971, 1972, and 1977). Sixteen of these 22 instances are denoted as "military faction" in the PRIO/Uppsala documentation "Armed Conflicts 1946-2004," and 17 instances appear in the list of 188 coups by McGowan (2003, appendix A). An 18th, Tunisia, is outside of McGowan's sub-Saharan database. The data thus seem to report other types of isolated violent episodes. Moreover, anything termed a civil war with a duration of only one year seems suspicious. For example, the violent episode in northern Nigeria that produced the 2004 entry was one of many in Nigeria's violent post1970 history. This conflict appears in the data as an intensity 1-3 event (25 or more deaths) and thereby assumes the same civil war status in an MGB-type coding as the years when Biafra attempted to secede from the Federation. Other instances in northern Nigeria are the Maitatsine risings in the early 1980s. None of these many violent episodes threatened the effective monopoly of force of the Nigerian state, which repressed them brutally. 
5. Casual inspection of the data in table 1 shows that there is clustering of the years of civil war produced by the death-based coding rule. This property is true regardless of whether the intensity is "war" (row 1), with its spotty coverage, or the merger of intensities 1-3 (row 2), although it is more pronounced in the latter case. This observation does not require the support of formal statistical analysis. This feature of the data is expected because almost any classification of countryyears into civil war or its absence must include the sustained nature of these conflicts. Following the third point above, if country narratives establish that the gaps between years of civil war in table 1 are also years of civil war, the autocorrelation of these series would increase because additional years of civil war would be followed by civil war, and likewise for years of peace. Trite as these observations may be, econometric studies of civil war have ignored their implications.

Proper regard for the statistical properties of the errors in the relationship between the dependent variable and the explanatory variables is key to reliable econometric inferences. The autocorrelation of the dependent variable, whether a country had a civil war in any given year, which is evident in table 1, is not a sufficient condition for the errors for each country in an econometric equation explaining whether a country had a civil war to be correlated across years. It is, however, highly suggestive of autocorrelation in the errors and requires that econometric analysis pay special attention to this possibility. However, econometric studies of whether countries have civil wars have not tested for this property of the error terms or corrected for autocorrelation. Two problems ensue if autocorrelation in the error terms exists but is ignored. First, levels of statistical significance reported in econometric studies are likely to be exaggerated, making it seem that inferences are reliable when they are actually the result of chance. Second, if the specification of the equation explaining civil war includes a variable defined as whether the country had a civil war in the preceding year, inferences will be biased if error terms are autocorrelated (the case of autocorrelated errors and a lagged dependent variable). Furthermore, we do not see autocorrelation as arising from some unmeasurable factor that is common to the civil war experience of all countries, such as the end of the Soviet Union's role in Africa. Rather, we see persistence in the dependent variable, whether there is a civil war, as arising from slow-moving, unmeasurable factors specific to each country's experience. Consequently, the problems posed by autocorrelation cannot be overcome by a set of controls common to all countries (year dummies, in econometric terminology), as would be justified in some econometric applications. 


\section{Among Large Groups of Inhabitants or Citizens of a Country}

So far, we have referred to episodes of large-scale violence as civil wars, in accordance with econometric studies. Now, we want to distinguish between civil wars and regional war complexes. The reasons for this distinction are twofold. First, the concept of a regional war complex emphasizes the interdependence of the largescale violence experienced by African countries. This interdependence is the source of the presumed correlation across countries in the dependent variable and associated error terms in the econometric models and is a severe problem for this research strategy. Second, the regional war complex is an essential building block for further exploration of large-scale violence in Africa through narratives. Basically, it provides a way of distinguishing the experience of Nigeria from 1967 to 1970 as a civil war from the experience of the countries in the five main regional war complexes in Africa that we identify and discuss in this section.

Central to our distinction between civil wars and regional war complexes is the extent to which "foreigners," who are neither inhabitants nor citizens of a country, are key participants (whether as providers of fighters, arms, bases, or other forms of assistance) in the violent conflict. A pivotal element in our definition of civil warand one that is shared, as noted earlier, by otherwise disparate definitions-is that the principal participants are inhabitants or citizens of the country experiencing the violence. That is, "domestic" participation (of inhabitants or citizens) is high, and "foreign" participation is low. In contrast, a regional war complex has high foreign participation, and domestic participation inside at least one of the countries involved in the violent conflict must be high enough to challenge the government's monopoly of force in that country. Regional war complexes must also be distinguished from international or interstate wars. Again, the critical dimension is the degree of foreign versus domestic participation. In an interstate war, foreign participation in the country experiencing the violence is high, and domestic participation is low. If the inhabitants or citizens are weak proxies or auxiliaries or are followers on the coattails of others, then the phenomenon is an international war. Distinguishing what constitutes high and low foreign versus domestic participation in a country experiencing violence requires judgments based on the historical narratives of large-scale violence. The challenge of delimiting the boundary between intra- and interstate wars (see Modelski 1964, 42; Cramer 2007, 70), which is considered by some to be a recent phenomenon (Levy 2007), inheres in our concept of a regional war complex.

We offer a tentative definition of a regional war complex that parallels our definition of a civil war: A regional war complex is a politically organized, large-scale, sustained, physically violent conflict among large groups of inhabitants or citizens of more than one country, and in at least one of these countries, at least two groups of inhabitants or citizens must be bona fide contenders for the monopoly of physical 
force. One way to think of the threshold of bona fide contenders is that each of these groups must be mounting efforts comparable to what would be expected of participants in a civil war. Groups that engage in violent conflict with each other but do not contest the state, which interest some researchers (e.g., Williams 2011), fall outside our purview. Most often, violence occurs in more than one country, and these multiple violent conflicts overlap or interlock and thus mutually reinforce, in practice, a distinctive attribute of a regional war complex.

The concept of regional war has been addressed explicitly, but much less frequently than the concept of civil war (Gleditsch 2007). We highlight a few key differences between two of these conceptions and our own definition. Wallensteen and Sollenberg (1998) find that more than half of the armed conflicts in the world between 1989 and 1997 were linked to conflicts in neighboring states. Merely on the basis of this simple count, these authors suggested the importance of "regional war complexes." They do not require, as we do, that at least one of the linked conflicts have two groups of citizens or inhabitants contending for the monopoly of force. Recently, Rubin et al. (2001) advocated the concept of a regional conflict formation to understand the conflict in the Great Lakes region and to contribute to conflict management in this region. Rubin et al. $(2001,3)$ define a regional conflict formation as "a set of transnational conflicts that form mutually reinforcing linkages with each other across state borders." These authors consider regional conflict formations to be armed conflicts that are not local, civil, or intrastate and that are contemporary phenomena. Our notion of a regional war complex differs from that of Rubin et al. in at least two ways. First, we require at least one country in the complex to have two groups of its citizens or inhabitants contending over the monopoly of force. Second, as discussed below, we believe that regional war complexes are not only contemporary but also historical phenomena.

Although the concept of regional wars has not been widely used, some of the dynamics that characterize such wars have been analyzed for many decades. At least since the 1960s, scholars have examined the role of external influences, including neighboring countries, on internal political violence (Rosenau 1964; Midlarsky 1992; Zartman originally published 1966, reissued 1989). Scott (1964) described the dynamics of how poor states that lack conventional capabilities, such as resources, population, and military power, can foment internal violence in other countries without great expense, thus destabilizing international politics. Zartman (1987, 1989 and 1992) described the high incidence of state propaganda and financial and military support of opposition groups intended to weaken the target state and the broader regional relations of neighbors and more distant states. In studies of civil wars, many case studies discuss the theme of regional influences on a particular civil war but do not delve into the dynamics that lead to these regional influences, which lie outside the scope of a single case as defined by these authors. For instance, studies of Chad (Azevedo 1998; Nolutshungu 1996) refer to Libya's 
role but do not consider the situation from the Libyan side. There have been many efforts to examine systematically the role of neighboring countries in intrastate wars. Brown (1996) argues that most internal violent conflicts are caused by the actions of internal elites. On the few occasions when external forces trigger violent internal conflicts, the "bad" actions of neighboring states play a more prominent role than mass-level or spillover phenomena. Woodwell (2004) discusses some aspects of ethnic commonalities among neighboring countries and their probabilities of experiencing civil wars. Since the 1960s, scholars of regional subsystems have highlighted the importance of geography in defining patterns of conflict and cooperation that characterize contiguous states (Khadiagala 2006). The more recent literature on regional security systems discusses how even noncontiguous states may be members of a regional system (Lake and Morgan 1997). Salehyan (2009) is interested in analyzing endogenous regional conflict clusters formed by the intrinsic links between civil wars and international conflicts. The bridge between the two types of mutually constituted and mutually reinforcing wars is provided by transnational rebel sanctuaries, which generate international hostilities and empower rebels in their struggles against their own state (Salehyan 2009, 50).

Our distinction between a civil war and a regional war complex is superficially similar to that made by PRIO/Uppsala between "internal armed conflict" and "internationalized internal armed conflict." Our concepts and those of PRIO/Uppsala share a recognition of the importance of external involvement as a factor that has the capacity to alter thinking about these experiences of large-scale violence. Our concept differs in practice from the concept implemented by PRIO/Uppsala because we consider much more of the African violence to be part of regional war complexes, as argued below in our discussion of table 1. By contrast, users of these data, such as MGB, lump both of these categories of conflict together under the heading "civil war."

In Africa, the episodes that are popularly termed civil war and that are coded as such in the econometric studies are often not predominantly internal conflicts. The Nigerian Civil War over Biafra's attempted secession from the Federation is an exception to most so-called civil wars in Africa in many ways and thereby provides an instructive case (coded entirely and appropriately by Xs in table 1). Its inception was an entirely domestic affair. Following political troubles in the Western Region, two bloody coups and pogroms against Ibos outside the Eastern Region and their flight home, the Ibo-dominated Eastern Region attempted to secede as Biafra from the spring of 1967. The war involved fighting by massed armies commanded by officers, many of whom had been former colleagues in the federal army, just as the opposing officers had in the American Civil War, and with every other attribute of structured combat. Biafra sustained itself for over three years of organized combat in the form of offensive and defensive campaigns and with plausible prospects of success at different junctures. Both belligerents maintained essentially all the de 
jure and de facto attributes of states, a capital, a civil administration, international representation, a currency, and postage stamps. The Nigerian war ended with a formal military surrender, similar to Appomattox, on January 12, 1970.

Foreign intervention was not absent from the conflict. Although combat was almost exclusively by nationals of what had been the Federation of Nigeria, arms supplied by non-African countries to each side were certainly important. The United Kingdom and Soviet Union supplied the Federalists, and France supplied Biafra, although Biafra's own purchases from arms suppliers were probably more important. Furthermore, Portugal, Côte d'Ivoire, and Gabon assisted in the airlift of arms to Biafra and other countries, including Tanzania, and Zambia recognized Biafra (De St. Jorre 1972; Stremlau 1977).

Nigeria is the most compelling (and, arguably, the only) civil war case in postindependence sub-Saharan Africa. The war began because of domestic conflict, and two large groups of Nigerians contested the integrity of the country. The main foreign participants provided arms (and relief) to domestic actors, which affected the dynamic of the conflict. Ultimately, however, the war remained primarily a contest between domestic actors and was resolved by internal factions. In short, foreign participation was low, and domestic participation was high. Moreover, foreign participation did not result in an interlocking regional conflict. Indeed, the most involved foreign actors were not even neighbors of Nigeria.

The exact identification of the regional war complexes, their membership, and timing is a demanding research effort because it involves piecing together many narrative accounts and making judgments on the importance of outsiders' involvement. However, we believe that a tentative list of the major war complexes and their members is feasible by utilizing commonly available knowledge. We identify the following complexes in Africa and their member countries within Africa: (1) Mano River (Burkina Faso, Côte d'Ivoire, Guinea, Liberia, Libya, Sierra Leone, and Senegal); (2) Chad (Central African Republic, Chad, Libya, and Sudan); (3) The Horn (Djibouti, Eritrea, Ethiopia, Kenya, Somalia, now in its several parts, and Sudan) (4) Great Lakes (Angola, Burundi, Central African Republic, Chad, Congo-Brazzaville, Congo-Kinshasa, Libya, Namibia, Rwanda, Sudan, Tanzania, Uganda, Zambia, and Zimbabwe); (5) South (Angola, Botswana, Lesotho, Malawi, Mozambique, Namibia, South Africa, Swaziland, Tanzania, Zambia, and Zimbabwe).

Regional war complexes and their participants are diverse. From our identification of the members of these complexes, it is evident that a country (e.g., Sudan) can participate in more than one complex. In some cases, a complex may begin as a civil war or two or more independent civil wars and then merge into a regional war sustained by important interactions among the participants. It may even begin as an international war and become a regional war complex. In general, ending some conflicts in a complex may disrupt the links that began or fueled wars and thereby may initiate a regional peace process. This dynamic is one measure of the 
interdependence of these episodes of violence and a practical consequence of thinking about them in this way because it can help to design strategies for establishing peace. $^{2}$

Some members of these complexes contribute importantly to violence in other African countries without experiencing violence as a consequence. Thus, Qadhafi's Libya played an extensive role in the violence in Chad, in the Mano River complex, and even (highly unsuccessfully) in the Ugandan/Tanzanian war that overthrew Amin (Lemarchand 1988; Huliaras 2001; Solomon and Swart 2005). Qadhafi's Libya is notable for the ambition of its reach into countries with which it is not contiguous. Except for one I in table 1 when it was active in combat in Chad, its activities are coded with an F, but this information does not identify where Libya was intervening. Burkina Faso's involvement in the Mano River complex is another example of an important player that has thus far avoided internal violence. Except for 1987, when it experienced a coup that seems to be the source of the X, Burkina Faso does not appear in table 1. According to the coding rules, it is at peace as much as any country in the sample. In addition to African countries, other countries that play this role are outside of Africa, including Cuba, France, the United States, and countries acting under the aegis of the United Nations, which have sent ground troops to participate in African conflicts.

Most of the countries that participate in these complexes are involved in reciprocal interactions, however, in which one country supports antagonists in a neighboring country and the neighbor responds in kind. Such pairs include Sudan and Uganda, Angola and Congo-Kinshasa, and Liberia and Côte d'Ivoire, among many others. Yet, the PRIO/Uppsala data record few if any of the international activities of Burkina Faso, Liberia, Libya, Sierra Leone, Côte d'Ivoire, or Somalia, among others. This lack of information means that econometric studies based on these data cannot incorporate such intercountry relationships even if they use specifications based on neighborhood effects, as in the spatial econometric literature (see below).

Côte d'Ivoire has been a long-time member of the Mano River complex, influencing the dynamics of the complex well before it experienced associated violence and, in particular, providing a launching place for Taylor's invasion of Liberia in 1989. From the coup attempt of September 19, 2002, until at least 2011, it has experienced a violent contest over the monopoly of force within its own borders. This contest is tied to the dynamics of the Mano River war complex (International Crisis Group 2003, 2004, 2007; Banégas and Marshall-Fratani 2007, especially 99).

The coup plotters in 2002 were Ivorian soldiers from the north of Côte d'Ivoire who were given shelter in Burkina Faso, from where they launched their coup. In September 2002, a French (Licorne) force separated the north from the south, preserving the Gbagbo government and thwarting the coup leaders, who were left controlling the north of the country. In November 2002, revolt broke out in the west of the country to the south of the French-maintained line of (temporary) partition. 
The situation in the west involved the participation of Ivorians and Liberians in each other's conflicts. The United Nations provided peacekeeping forces in February 2004. In November 2004, the French forces destroyed the Ivorian air force of the Gbagbo government in retaliation for the killing of peacekeepers and an aid worker by the air force. Finally, in 2011, French and United Nations forces intervened in the postelection violence consequent on Gbago's refusal to accept the election results of November, 2010. Thus, foreign forces from noncontiguous countries played important roles in this conflict.

These events have their origins long ago, however, in the colonial and postcolonial economic strategies of the Ivorian economic miracle with its focus on labor movement from outside and from within Côte d'Ivoire to its tree-crop producing areas. In the receiving areas, especially the southwest, this movement led to potential conflict between the established people and the newcomers, especially over land rights. There are two regional consequences. First, any dynamics within Côte d'Ivoire that threatened immigrants, especially the numerous Burkinabés, would have implications for the neighboring governments in protecting their citizens abroad and in dealing with potentially large return migrations of refugees. Second, dissatisfaction and unrest between the groups of established and recently arrived citizens within Côte d'Ivoire would provide opportunities for intervention from neighboring Liberia, especially because ethnic conflicts in Liberia mirrored divisions in Côte d'Ivoire. Because recent events proceed from these deeply structural factors that operate on a regional level and because the particulars of the conflict that began in Côte d'Ivoire in 2002 involved specific violent interventions by neighboring countries in each other's affairs, we designate the Ivorian experience as part of the Mano River complex.

PRIO/Uppsala, however, do not code for the many interactions among countries evident in this history. Therefore, an MGB-type coding also misses them. PRIO/ Uppsala only code Côte d'Ivoire as experiencing conflict at the "minor" intensity level and only beginning in 2002, thereby ignoring its participation in the violence of the Mano River complex before 2002. This coding also neglects the important roles of outsiders in the violent Ivorian experience beginning in 2002: there is no recognition in the coding of the role of Burkina Faso in hosting soldiers from northern Côte d'Ivoire who engaged in a coup and the subsequent partition of the country. The distant French and the contiguous neighbor Liberia were implicated in the post-2002 Ivorian conflict, but this involvement is not coded either.

We consider Mozambique's conflict between Renamo and the Frelimo government (Vines 1991; Finnegan 1992; Hume 1994) part of a regional war complex rather than a civil war, as MGB's econometric studies do (table 1 ). ${ }^{3}$ To begin to understand this post-independence conflict, one must acknowledge its inextricable links to the internal and external politics of the wars to decolonize Mozambique and Rhodesia. During the struggle for independence in Mozambique, Frelimo invited 
Mugabe's ZANLA army to establish military bases and refugee camps in Frelimooccupied territory. Rhodesians retaliated by attacking the camps and bases, thus regionalizing the conflict. After Frelimo became the government in Mozambique, the Rhodesian government continued to attack ZANLA bases and attempted to destabilize the Frelimo government by providing financial support to Renamo rebels. Renamo itself drew in part upon people who had been marginalized in political conflicts within Frelimo during and after the struggle for independence as well as upon those who opposed Frelimo's policies. After Mugabe's party formed the government of Zimbabwe, the South African government took over the training, financing, and arming of Renamo rebels. The Frelimo government provided bases to African National Congress guerrillas who infiltrated South Africa through southern Mozambique. Mugabe provided military support to the Frelimo government, his former liberation war ally. Renamo retaliated against Zimbabwe's intervention by attacking villagers living close to the Mozambican border. The war between Renamo and Frelimo ended in an externally mediated peace agreement in 1992 that was possible, in part, because South Africa and Zimbabwe ceased to intervene on behalf of their respective allies. Thus, regional dimensions are crucial to understanding the origins, dynamics, and ending of large-scale violence in Mozambique. Keller (1997) correctly views the domestic conflict in Mozambique as having contributed to regional insecurity in southern Africa. However, as we have shown, the "domestic" conflict in Mozambique was itself an inextricable product of regional interventions. This conflict is best viewed as a component of a regional war complex rather than a civil war or a domestic conflict with regional dimensions.

Labeling the war between Renamo and Frelimo in Mozambique a "civil war," as MGB do, is therefore a misnomer. Foreign participation in sponsoring, training, and equipping Renamo, first by the Rhodesian government and then by the South African government, played a vital role in making Renamo a serious contestant for the monopoly of force. However, Renamo was not a mere proxy of its foreign benefactors because it had substantial domestic support. South African support for Renamo and Frelimo support for the African National Congress represent examples of "interlocking" conflict, as did Zimbabwean support for Frelimo and Renamo attacks on Zimbabwean civilians on the eastern border. Violence was not contained inside Mozambique; it also occurred within Zimbabwe and South Africa. Finally, the disruption of regionalized links - South African and Zimbabwean support for their respective allies-facilitated the peace.

Another example of interdependent violent conflict and its consequences for peacemaking comes from the Sudan-Uganda interaction. Uganda supported southern opponents of the Khartoum government after Khartoum began to support opponents of the Uganda government in northern Uganda in 1986 and subsequently within Sudan (Prunier 2004). With the Comprehensive Peace Agreement of January 2005 that ended the war between southern Sudan and the Khartoum 
government, security problems in northern Uganda subsided, although the Lord's Resistance Army opponents of the Kampala government remain active in parts of Congo-Kinshasa, the Central African Republic, and southern Sudan. From an econometric perspective, to the extent that conflicts end because regional conflicts wind down, there is correlation in the outcomes and, presumably, the error terms among the countries in samples used to study the duration and ending of civil wars.

Congo-Kinshasa (former Zaire and henceforth Congo, when the context is clear) is a major participant in another regional war complex that we call the Great Lakes complex. Table 2 illustrates how four datasets used by econometricians all classify Congo in the 1990s as having experienced civil war. The MGB studies code a civil war based on the concept of "internationalized armed conflict" from 1997 to 2000 as intensity 3 and that from 1996 to 2001 as intensity $1-3$. Their coding rule does not indicate whether the years coded as civil war constitute one or more such wars. The other two datasets code two civil wars each. Fearon and Laitin (2003b) code one from 1996 to 1997 and another from 1998 to 1999. Doyle and Sambanis (2006) also code one civil war from 1996 to 1997 and another from 1998 to 2001. We prefer to view the conflict in Congo during the 1990s and into the 21st century as a regional war complex with two major phases rather than as one or two civil wars. We only hint below at the multiple layers of actors, alliances, and interests involved in this complex. We believe that this complex has existed since many of its member countries attained political independence, but we cut into its dynamics only from the mid-1990s.

The war in 1996 to 1997 was fought primarily to remove Mobutu Sese Seko, dictator from 1965 to 1997 . Internal opposition forces were too fragmented to remove Mobutu, but he was widely disliked inside the country. Many African leaders had considered joint military intervention to remove Mobutu, whom they viewed as an embarrassment and an imperialist stooge. Rwanda's postgenocide government unilaterally took the initiative, followed soon thereafter by Uganda. These were the major players in the violent conflict that finally removed Mobutu and installed Laurent Kabila in May 1997.

Rwanda's interests were chiefly security driven. The 1994 Rwandan genocide, in which extremist Hutus killed Tutsis and moderate Hutus, was followed by the taking of power in Rwanda by Tutsis, mostly former refugees who had been in Uganda. In turn, many Hutus, including extremists, fled as refugees into the eastern parts of Congo abutting Rwanda. The extremists took control of the Hutu refugees in Congo. These extremists, who first wanted to retake and then merely to destabilize Rwanda, launched attacks from Congo. The Rwandan government wanted to defeat them and end this threat on its borders.

Uganda joined Rwanda's effort to oust Mobutu primarily because Mobutu had allowed Ugandan rebels to operate against President Museveni's government from the northeastern corner of Congo. These rebels were aided by Museveni's 
longstanding enemy, the government of Sudan, which hoped to use the Ugandan rebels not only to destabilize Uganda but also to Islamize Ugandans. Uganda had close ties to the rebels in southern Sudan who fought the Sudanese government.

Uganda and Rwanda joined forces with a weak Congolese rebel force led by Kabila. Some analysts believe that the military role of the Congolese rebel force was nominal, and its external formation primarily served to conceal the Rwandan and Ugandan invasion (Turner 2007; Lemarchand 2009; Nzongola-Ntalaja 2002; Kennes 2005; Prunier 2009). Other analysts credit the military role, leadership, and initiative of the Congolese rebels and refer to military support from Kabila's Rwandan, Ugandan, and other allies (Ndikumana and Emizet 2005; Zartman 2005; Baregu 2006; Adebajo 2006) or seem unconcerned by the nationality of "ethnic Rwandans" (presumably meaning Tutsi) who "heavily dominated" the Congolese rebel force (Reed, 1998). Whether the Congolese rebels are portrayed more as "clients" or "proxies" of their external patrons or more as genuine partners or allies, together they drove Mobutu from power with little resistance. Kabila became president and initially kept Rwandan officers in charge of his new army.

The war continued — or, as most analysts claim, another war began in 1998when President Kabila ordered the Rwandan troops in Congo to return to Rwanda. The Rwandan army, the Ugandans, and Congolese rebel forces responded by acting to remove Kabila. Rwanda and Uganda no longer trusted Kabila to serve their security interests, and the otherwise disparate Congolese rebels were united solely by a desire to seize power themselves. Analysts again are divided between those who see the Congolese rebel organizations as "proxies" or "clients" of the Rwandans and Ugandans who created, financed, equipped, provided personnel for, and largely controlled the organizations (including the appointment of their leaders) that served as a cover for their own interests (Lemarchand 2009; Prunier 2009; Kennes 2005; Nzongola-Ntalaja 2002; Ndikumana and Emizet 2005; Tull 2003, 2007) and others who consider the Congolese rebel organizations to have merely enjoyed external support from their foreign allies (Zartman 2005; Baregu 2006). Jean Bemba's organization is typically considered to have developed autonomy from his Ugandan sponsor.

Analysts debate why Rwanda and Uganda invaded Congo in 1998. This discussion of motives highlights the regional dimensions and mutually interlocking dynamics in the Great Lakes complex. Some give primacy to their continued security interests (Tull 2007), others emphasize their aggressive quest for access to and control of Congo's rich resources (Baregu 2006), and still others consider the security concerns expressed by Rwanda and Uganda to be mere pretext for access to Congo's natural resources (Nzongola-Ntalaja 2002). Turner (2007) argues that Rwanda, Uganda, and Burundi intervened in 1998 to secure their respective western borders against rebel movements based in Congo and to gain access to Congo's resources. Many observers argue that security concerns were the initial 
primary driving force behind Rwanda's 1998 invasion, but economic exploitation of Congo's resources became the main (albeit unacknowledged) reason (Reyntjens 2006; Lemarchand 2009).

For some (Kennes 2005; Zartman 2005), the fundamental stakes in both wars were the struggle for regional hegemony in the power vacuum created by Mobutu's loss of control. Kabila's key military allies were Zimbabwe, Angola, and Namibia. Chad was a reluctant participant, responding to the request of its ally Sudan to provide troops that were transported to Congo on Libyan planes (Prunier 2004). Some emphasize the pan-Africanism of Kabila's three key military allies (Baregu 2006), and others emphasize their different interests. Some stress the economic motives of Zimbabwe (Prunier 2006; Nzongola-Ntalaja 2002; Lemarchand 2009), whereas others point to Mugabe's rivalry with South Africa for regional hegemony (Kennes 2005). Most analysts highlight Angola's security concerns to prevent its rebel opponent, UNITA, from reestablishing bases in Congo (Nzongola-Ntalaja 2002; Lemarchand 2009; Prunier 2009), whereas Namibia is seen as either following its patron, Angola (Prunier 2006 and 2009), or as having an interest in the water and hydroelectric resources in Congo and security concerns to prevent UNITA from destabilizing Angola (Nzongola-Ntalaja 2002).

The discussion above merely sketches the most important players in the violence that engulfed Congo beginning in 1996. It omits how states such as the Central African Republic, Congo-Brazzaville, Burundi, Tanzania, Zambia, Kenya, Gabon, and South Africa directly or indirectly played a role in the war(s) in Congo, as did many armed and unarmed nonstate actors. Several members in the complex are not contiguous with Congo. South Africa and Zambia played a major role in brokering peace in Congo, beginning with accords in 1999. However, eastern Congo continued to be beset with violence even after peace had been restored elsewhere in the country under Joseph Kabila, who became president after his father's assassination in 2001.

Unlike a number of scholars who use an econometric approach (table 2), analysts using a narrative approach are divided on whether the war or wars in Congo (1996-2002) had a civil war component. Those commentators, such as Kennes (2005), Turner (2007), Prunier (2009), and Lemarchand (2009), who deny the Congo war or wars the status of civil war, consider the conflict to have been fought primarily by foreigners hiding behind weak internal proxy forces that lacked the capability to sustain a civil war. The foreigners, as discussed, were both neighboring states and more distant states as well as nonstate actors who were in Congo to wage war against their home governments.

In fact, if the years from 1996 and afterward are to be coded as anyone's civil war, it might make more sense to code them as a continuation of Rwanda's rather than Congo's (Reyntjens 2006, 30). The conflict between certain Tutsi and Hutu groups within Rwanda spilled into Congo. Similarly, Angola's experience was more 
of a civil war than Congo's, and it too spilled over into Congo. Thus, both of these countries' experiences meet the requirement of our definition of a regional war complex, with at least one country having a contention for the monopoly of force between domestic groups that proceeds at high intensity. At the same time, the experience of the Great Lakes complex as a whole is one of interlocking and reinforcing conflicts within and among many countries, which is why we consider it a regional war complex.

The Congo conflict underscores the ongoing importance of regional conflicts involving state and nonstate armed actors in understanding mass violent upheaval in Africa. The Congo conflagration also sharply raises the questions of how one defines a civil war and how one distinguishes between civil wars fought with regional support and foreign invasions fought with foreign-controlled proxies. We do not count the violent conflicts between Congolese forces that occurred in Congo (1996-2002) as civil wars because of the preponderant role of foreign forces fighting in Congo and the associated violence outside Congo's borders. Importantly, the interconnected episodes of violence in 1996-1997, 1998-1999, and thereafter demonstrate the difficulty of determining when an old war ends and a new war begins.

Our narratives establish important interdependencies within groups of countries in these contestations over the monopoly of force. In turn, such interdependencies pose problems for econometric research on civil war. Current research on civil wars does not correct or adequately test for these possibilities, creating a set of potentially serious misspecifications that may lead to an overstatement of statistical significance of, and even bias in, parameter estimates. These interdependencies among countries regarding whether a country has a civil war can enter econometric specifications in several ways.

The first (and most simple) way is if variables based on the characteristics of other countries enter the list of explanatory variables, such as information on the religions or ethnicities in neighboring countries. Such variables pose no additional econometric problems relative to a variable based on a country's own characteristics.

The second way is if there is correlation among the errors in explaining whether countries have civil wars or if the list of explanatory variables includes whether other countries, perhaps contiguous ones, are experiencing civil war, or both. These formulations pose estimation problems. For instance, if country A's outcome (whether it has a civil war) partially determines B's outcome, then the error term for A influences the outcome for B. However, B's outcome also influences A's outcome. In other words, some of the explanatory variables (the other countries' outcomes, say, B's) are correlated with the error in the equation for the country under consideration (say, A). Special estimation techniques can avoid biased estimators if the intercountry relationship is simple, such as spillovers between contiguous neighbors (LeSage and Pace 2009). The narratives, however, suggest that 
influences of other countries on outcomes in a particular country are more complicated than easily permitted by econometric specifications. For instance, Libya was highly active in fomenting violence but had experienced almost no violence of the sort recorded in Table 1 prior to its own civil war of 2011, and it is not a contiguous neighbor of the countries that experienced violence in two of the complexes in which Libya has played a role. Beck et al. (2006) point out that problems do not arise if the explanatory variable is whether another country had a civil war in the preceding rather than the current year, but their point is only relevant if the errors are not correlated over time. As argued in the preceding section, however, there is reason to expect that errors are autocorrelated when data look like they do in table 1.

The third way is if there are both correlations over time and across countries, as we have argued. For instance, the value of the lagged dependent variable for the country in question, whether it had a civil war in the preceding year, and the contemporaneous values of the dependent variable for other countries, whether they had civil wars, may be among the variables that explain the dependent variable of each country. In addition, the errors in the explanatory equations for each country may be correlated over time and across countries. ${ }^{4}$

Among the limited number of studies that have attempted some type of spatial analysis of what they consider civil war are Fearon and Laitin (2003a), Gleditsch (2007), and Buhaug and Gleditsch (2008). The latter two are highly ambitious in their econometric procedures, although they do not adopt a full-fledged correction for correlation over time and across countries. Even if one persisted and somehow estimated a model that was flexible enough to encompass (nest) the pervasive correlation over time and space that must be presumed to characterize these countries' experiences, it is implausible that precise findings would emerge regarding the processes at work. The implied likelihood functions would have too many parameters, and the numbers of observations would be too few. Available results from incomplete implementations of the more encompassing specifications establish an econometric presumption that spatial interdependencies cannot be ignored. This conclusion is supported by Buhaug and Gleditsch $(2008,227)$, who study the onset of civil war and find that their fixed-effect estimator yields mostly insignificant results, nonetheless an indicator of whether there is conflict in neighboring countries retains significance. Similarly, in their reanalysis of Miguel et al. (2004), Jensen and Gleditsch $(2009,368)$ demonstrate that the key finding of the former study on the role of rainfall in predicting civil wars (through its effect on income) is attenuated, in some cases to the point of statistical insignificance, by the inclusion of spatial effects in the explanatory equation. This result is consistent with a conclusion that rainfall is just a proxy for regional effects. The presumed importance of such regional effects, supported by the Buhaug-Gleditsch and Jensen-Gleditsch studies, is exactly the conclusion of our narratives. 
These spatial interdependencies also have implications for authors such as Goldstein and Pinker (2011), who attempt to conclude that there is a decline in the prevalence of wars. Because many of these wars form complexes, the countries that are involved may tend to return to a peaceful status at nearly the same time. If it were assumed that the end of violence in a number of countries represented independent events, it might make sense to infer a trend toward peace and to look for its causes. However, if the end of violence in a number of countries is not independent, then there is not a sufficient number of observations to make confident inferences. For this reason among others, the type of inferences that Angell (1910) made about the prospects for peace are always risky.

Fundamentally, the interdependencies among countries raise the question of whether the unit of observation is the individual country or the regional war complex. Econometric studies seem to struggle to incorporate these interdependencies. By contrast, an analysis based on the narratives can easily focus on the regional complex as the unit of observation.

\section{Conclusions}

As we initially stated, we believe that a list of country-years classified into civil war or membership in a regional war complex or the absence of these situations requires a detailed compilation of country histories based on the case-study literature. This task is feasible for the five regional war complexes we have identified as well as others elsewhere in the world. We believe that the outcome will be the documentation of regional war complexes rather than properly defined civil wars. This task is large, and this paper begins to clear the way by attempting to craft definitions that distinguish civil wars from regional war complexes and to show how to use these definitions. The periodization of civil wars and regional war complexes must depend on many judgments and their justifications. Important aspects of these justifications will be the level and nature of violence and whether violence spills across borders, the extent of participation, the organization of the parties to the conflict, the purposes of the conflict (both stated by the participants and inferred), the plausibility of contention over the monopoly of force, the duration of the conflict, the freedom of movement in the country, the ability of a government to fulfill functions such as revenue collection, and the role of one country in the affairs of others. These are some of the relevant components of Wittgenstein's complicated network of definitional similarities for large-scale violent political conflict, whether a civil war or a regional war complex, that will set the context for the analysis of cause and consequence.

Regardless of the relative difficulties of producing narratives for a complex, we have stated why the econometric literature fails to provide a convincing analysis of 
these episodes of violence in its own terms, so there is no solution here. For these reasons, we believe that the energy of researchers should turn to a comparative analysis of regional war complexes based on narratives extracted from the casestudy literature.

\section{Notes}

Mark Gersovitz is Professor in the Department of Economics, The Johns Hopkins University; email address: gerso@att.net. Norma Kriger is an Independent Consultant currently on contract at the Federal Research Division of the Library of Congress. We thank Timothy Besley, Henry S. Bienen, Richard H. Spady, and Tiemen M. Woutersen for their valuable comments.

1. Of course, an updated version of the data set would record a civil war in Libya for 2011, in which Qadhafi fell, albeit with considerable, perhaps determinative, help from NATO.

2. King $(2007,126)$ writing about civil wars understood as large-scale violence within the boundaries of a single state, notes that peace agreements "that build in a regional dimension - seeing the organizations of violence, in effect, as extending well beyond the borders of the state concerned - have now become a critical component of successful war termination." Building regional dimensions into conflicts conceptualized as "civil wars" risks underemphasizing how fused the experiences of groups of these countries have been.

3. Table 1 codes the years of war in Mozambique as either an internal armed conflict or an internationalized armed conflict. An MGB coding rule would term them, collectively, years of civil war.

4. Driscoll and Kraay (1998) and Pesaran and Tosetti (2011) provide methods for dealing with errors that are correlated across both countries and years without placing restrictions on the form of the correlations. Driscoll and Kraay (1998) show the possibility of a large overstatement of statistical significance if such methods are not adopted. However, the methods of these authors do not directly apply to the case in which temporal and spatial lags of the dependent variable (whether there are civil wars in other countries or in earlier years in the country under consideration) may appear as explanatory variables.

\section{References}

Adebajo, A. 2006.“The United Nations.” In Security Dynamics in Africa's Great Lakes Region, ed. G. Khadiagala, 235-68. Boulder, CO, and London: Lynne Rienner Publishers.

Angell, N. 1910. The Great Illusion: A Study of the Relation of Military Power in Nations to Their Economic and Social Advantage. New York: Putnam's.

Atlas, P. M., and R. Licklider. 1999. "Conflict Among Former Allies After Civil War Settlement: Sudan, Zimbabwe, Chad, and Lebanon." Journal of Peace Research 36:35-54.

Azevedo, M. J. 1998. Roots of Violence: A History of War in Chad. Amsterdam, The Netherlands: Overseas Publishers Association.

Baev, P. K. 2007. "Defining Civil War by Examining Post-Soviet Conflicts.” Terrorism and Political Violence 19:247-68.

Banégas, R., and R. Marshall-Fratani. 2007. "Côte d'Ivoire: Negotiating Identity and Citizenship" In African Guerrillas: Raging against the Machine, eds. M. Bøås, and K. C. Dunn, 81-112. Boulder, CO: Rienner. 
Baregu, M. 2006. "Congo in the Great Lakes Conflict." In Security Dynamics in Africa's Great Lakes Region, ed. G. Khadiagala, 98-131. Boulder, CO, and London: Lynne Rienner Publishers.

Beck, N., K.S. Gleditsch, and K. Beardsley. 2006. "Space is More than Geography: Using Spatial Econometrics in the Study of Political Economy." International Studies Quarterly 50:27-44.

Blattman, C., and E. Miguel. 2010. "Civil War." Journal of Economic Literature 48:3-57.

Bøås, M., and K. C. Dunn. 2007. “Introduction.” In African Guerrillas: Raging Against the Machine, eds. M. Bøås, and K. C. Dunn, 1-8. Boulder, CO: Lynne Rienner.

Brown, M. E. 1996. "Introduction," and "The Causes and Regional Dimensions of Internal Conflict." In The International Dimensions of Internal Conflict, ed. M.E. Brown, 1-31 and 571-601. Cambridge, MA: MIT University Press.

Buhaug, H., and K. S. Gleditsch. 2008 "Contagion or Confusion? Why Conflicts Cluster in Space." International Studies Quarterly 52:215-33.

Collier, P., and A. Hoeffler. 2007. "Civil War." In Handbook of Defense Economics, eds. T. Sandler and K. Hartley, 711-39. Amsterdam, The Netherlands: Elsevier.

Cramer, C. 2007. Violence in Developing Countries: War, Memory, Progress. Bloomington, IN: Indiana University Press.

De St. Jorre, J. 1972. The Nigerian Civil War. London: Hodder and Stoughton.

Dixon, J. 2009. "What Causes Civil Wars? Integrating Quantitative Research Findings.” International Studies Review 11:707-35.

Doyle, M. W., and N. Sambanis. 2000a. "International Peace Building: A Theoretical and Quantitative Analysis.” American Political Science Review 94:778-801.

2000b. Data Set Notes, November 6, 2000. http://www.worldbank.org/research/conflict/ papers/peacebuilding.

2006. Making War \& Building Peace. Princeton, NJ: Princeton University Press.

Driscoll, J. C., and A. C. Kraay. 1998. "Consistent Covariance Matrix Estimation with Spatially Dependent Panel Data." Review of Economics and Statistics 80:549-60.

Eckstein, H. ed. 1964. Internal War: Problems and Approaches. New York: The Free Press.

1965. "On the Etiology of Internal Wars." History and Theory 2:133-63.

Edmonds, M. 1972. "Civil War, Internal War, and Intrasocietal Conflict." In Civil Wars in the Twentieth Century, ed. R. Higham, 11-26. Lexington, KY: University of Kentucky Press.

Fearon, J. D. 2007. “Iraq's Civil War.” Foreign Affairs 86:2-15.

Fearon, J. D., and D. D. Laitin. 2003a. "Ethnicity, Insurgency, and Civil War.” American Political Science Review 97:75-90.

Fearon, J. D., and D. D. Laitin. 2003b. "Additional Tables for 'Ethnicity, Insurgency, and Civil War." Stanford, CA: Stanford University.

Finnegan, W. 1992. A Complicated War: The Harrowing of Mozambique. Berkeley, CA: University of California Press.

Gleditsch, K. S. 2007. “Transnational Dimensions of Civil War.” Journal of Peace Research 44:293-309.

Gleditsch, N. P., P. Wallensteen, M. Eriksson, M. Sollenberg, and H. Strand. 2002. "Armed Conflict 1946-2001: A New Dataset." Journal of Peace Research 39:615-37.

Goldstein, J. S., and S. Pinker. 2011, December 17. "War Really is Going out of Style." New York Times.

Huliaras, A. 2001. "Qadhafi's Comeback: Libya and Sub-Saharan Africa in the 1990's.” African Affairs 100:5-25.

Hume, C. R. 1994. Ending Mozambique's War: The Role of Mediation and Good Offices. Washington, DC: United States Institute of Peace. 
International Crisis Group. 2003. "Côte d'Ivoire: The War is Not Yet Over.” Freetown/Brussels: ICG. 2004. “Côte d'Ivoire: No Peace in Sight.” Dakar/Brussels: ICG.

2007. "Côte d'Ivoire: Can the Ouagadougou Agreement Bring Peace." Freetown/Brussels: ICG.

Jensen, P. S., and K. S. Gleditsch. 2009. "Rain, Growth, and Civil War: The Importance of Location." Defence and Peace Economics 20:359-72.

Kalyvas, S. N. 2006. The Logic of Violence in Civil War. Cambridge, MA: Cambridge University Press.

Keegan, J., and B. Bull. 2006. "What is a Civil War?” Prospect Magazine, 129.

Keller, E. 1997. "Rethinking African Regional Security." In Regional Orders: Building Security in a New World, eds. D.A. Lake and P. Morgan, 296-317. University Park, PA: The Pennsylvania State University Press.

Kennes, E. 2005. “The Democratic Republic of the Congo: Structures of Greed, Networks of Need." In Rethinking the Economics of War: The Intersection of Need, Creed, and Greed, eds. C. I. Arnson, and I. W. Zartman, 140-77. Washington, DC, and Baltimore, MD: Woodrow Wilson Center Press and Johns Hopkins University Press.

Khadiagala, G. 2006. "Toward Peace, Security and Governance in the Great Lakes Region” In Security Dynamics in Africa's Great Lakes Region, ed. G. Khadiagala, 8-25. Boulder, CO, and London: Lynne Rienner Publishers.

King, C. 2007. "Power, Social Violence, and Civil Wars" In Leashing the Dogs of War: Conflict Management in a Divided World, eds. C.A. Crocker, F.O. Hampson, and P. Aall, 115-30. Washington, DC: United States Institute of Peace Press.

Kriger, N. 2003. Guerrilla Veterans in Post-War Zimbabwe: Symbolic and Violent Politics 1980-1987. Cambridge, MA: Cambridge University.

Lake, D. A., and P. M. Morgan, eds. 1997. Regional Orders: Building Security in a New World. University Park, PA: The Pennsylvania State University Press.

Lemarchand, R. 1988. The Green and the Black. Bloomington, IN: Indiana University Press. 2009. The Dynamics of Violence in Central Africa. Philadelphia, PA: University of Pennsylvania Press.

LeSage, J., and R. K. Pace. 2009. Introduction to Spatial Econometrics. Boca Raton, FL: Chapman \& Hall.

Levy, J. S. 2007. "International Sources of Interstate and Intrastate War” In Leashing the Dogs of War: Conflict Management in a Divided World, eds. C.A. Crocker, F. O. Hampson, and P. Aall, 17-38. Washington, DC: United States Institute of Peace Press.

Licklider, R. 1995. "The Consequences of Negotiated Settlements in Civil Wars, 1945-1993." American Political Science Review 89:681-90.

Luard, E., ed., 1972. The International Regulation of Civil Wars. New York: New York University Press.

McGowan, P. J. 2003. "African Military Coups d'Etat, 1956-2001: Frequency, Trends and Distribution." Journal of Modern African Studies 41:339-70.

Midlarsky, M. I. 1992. The Internationalization of Communal Strife. London: Routledge.

Miguel, E., S. Satyanath, and E. Sergenti (2004). "Economic Shocks and Civil Conflict: An Instrumental Variables Approach." Journal of Political Economy 112:725-53.

Modelski, G. 1964."The International Relations of Internal War." In International Aspects of Civil Strife, ed. J. N. Rosenau, 122-53. Princeton, NJ: Princeton University Press.

Ndikumana, L., and K. F. Emizet. 2005. "The Economics of Civil War: The Case of the Democratic Republic of Congo." In Understanding Civil War: Evidence and Analysis. Vol.1. Africa, eds. P. Collier and N. Sambanis, 63-88. Washington, DC: The World Bank. 
Nolutshungu, S. C. 1996. Limits of Anarchy: Intervention and State Formation in Chad. Charlottesville, VA: University of Virginia Press.

Nzongola-Ntalaja, G. 2002. The Congo: From Leopold to Kabila. New York and London: Zed Books.

Pesaran, M. H., and E. Tosetti. 2011. "Large Panels with Common Factors and Spatial Correlation." Journal of Econometrics 161:182-202.

Prunier, G. 2004. "Rebel Movements and Proxy Warfare: Uganda, Sudan and the Congo (1986-99)." African Affairs 103: 359-83.

2006. "The Economic Dimensions of Conflict in the Region." In Security Dynamics in Africa's Great Lakes Region, ed. G. Khadiagala, 168-202. Boulder, CO, and London: Lynne Rienner Publishers.

2009. Africa's World War: Congo, The Rwandan Genocide, and the Making of a Continental Catastrophe. Oxford: Oxford University Press.

Reed, W.C. 1998. "Guerrillas in the Midst: The Former Government of Rwanda (FGOR) \& the Alliance of Democratic Forces for the Liberation of Congo-Zaire (AFDL) in Eastern Zaire." In African Guerrillas, ed. C. Clapham, 134-54. Oxford: James Currey Ltd.

Reyntjens, F. 2006. "Governance and Security in Rwanda." In Security Dynamics in Africa's Great Lakes Region, ed. G. Khadiagala, 27-68. Boulder, CO, and London: Lynne Rienner Publishers.

Rosenau, J. N., ed. 1964. International Aspects of Civil Strife. Princeton, NJ: Princeton University Press.

Rubin, B. R., A. Armstrong, and G. R. Ntegeye, eds. 2001. Regional Conflict Formation in the Great Lakes Region of Africa: Structure, Dynamics and Challenges for Policy. Center on International Cooperation. 11-13 November 2001, Safari Park Hotel, http://www.cic.nyu.edu/peacebuilding/oldpdfs/ RCF_NAIROBI.pdf (accessed August 25, 2010).

Salehyan, I. 2009. Rebels without Borders: Transnational Insurgencies in World Politics. Ithaca, NY: Cornell University Press.

Sambanis, N. 2004. "What is Civil War?: Conceptual and Empirical Complexities of an Operational Definition." Journal of Conflict Resolution 48:814-58.

Scott, A. 1964. "Internal Violence as an Instrument of Cold Warfare." In International Aspects of Civil Strife, ed. J. N. Rosenau, 154-69. Princeton, NJ: Princeton University.

Solomon, H., and G. Swart 2005. "Libya' Foreign Policy in Flux.” African Affairs 104:469-92.

Strand, H., J. Carlsen, N. P. Gleditsch, H. Hegre, C. Ormhaug, and L. Wilhelmsen. 2005. Armed Conflict Dataset Codebook: Version 3-2005. Oslo, Norway: International Peace Research Institute. (www.prio .no/cscw/armedconflict)

Stremlau, J. J. 1977. The International Politics of the Nigerian Civil War, 1967-1970. Princeton, NJ: Princeton University Press.

Tull, D. M. 2003. "A Reconfiguration of Political Order? The State of the State in North Kivu (DRC)." African Affairs 102: 429-46.

2007. "The Democratic Republic of Congo: Militarized Politics in a "Failed State.” In African Guerrillas: Raging against the Machine, eds. M. Bøås, and K.C. Dunn, 113-30. Boulder, CO, and London: Lynne Rienner Publishers.

Turner, T. 2007. The Congo Wars: Conflict, Myth \& Reality. New York and London: Zed Books.

Vines, Alex. 1991. Renamo: Terrorism in Mozambique. Bloomington, IN: Indiana University Press.

Wallensteen, P., and M. Sollenberg. 1998. "Armed Conflict and Regional Conflict Complexes, 198997." Journal of Peace Research 35:621-34.

. 1999. "Armed Conflict, 1989-98." Journal of Peace Research 36:593-606.

Weber, M. 2004. "Politics and the State." In The Essential Weber: A Reader, ed. S. Whimster, 131-32. New York and London: Routledge. 
Williams, Paul D. 2011. War \& Conflict in Africa. Cambridge, UK: Polity.

Wittgenstein, L. 1958. Philosophical Investigations. Upper Saddle River, NJ: Prentice-Hall.

Woodwell, D. 2004. "Unwelcome Neighbors: Shared Ethnicity and International Conflict during the Cold War." International Studies Quarterly 48:197-223.

Zartman, I.W. 1987. International Relations in the New Africa. Millburn, NJ: University Press of America.

1989. Ripe for Resolution. Oxford: Oxford University Press.

. 1992. "Internationalization of Communal Strife: Temptations and Opportunities of Triangulation." In The Internationalization of Communal Strife, ed. M. I. Midlarsky, 27-42. London: Routledge.

2005. Cowardly Lions: Missed Opportunities to Prevent Deadly Conflict and State Collapse. Boulder, CO, and London: Lynne Rienner Publishers. 